\title{
TOWARDS SMARTER SPECIALISATION - KEY DRIVERS OF NANOTECHNOLOGY DEVELOPMENT IN PODLASKIE REGION
}

\author{
Lukasz Nazarko \\ Faculty of Engineering Management, Bialystok University of Technology, Wiejska 45A, \\ 15-351 Bialystok, Poland \\ E-mail: l.nazarko@pb.edu.pl
}

\begin{abstract}
The paper focuses on the issue of the approaches and methods used in the identification of regional smart specialisation areas. It is argued that foresight is a critical element in the formulation of a smart specialisation strategy. More extensive use of tools from the field of foresight and future studies may lead to smarter specialisations - the ones that anticipate the emergence of high-growth technologies and sectors. At the same time it is observed that foresight approach is insufficiently appreciated in Poland in this context. The case of Podlaskie voivodship is described. The results of a technological foresight project on nanotechnology development in Podlaskie voivodship is presented together with a proposal of a methodology for updating its results.
\end{abstract}

Keywords: smart specialisation, nanotechnology, Podlaskie, foresight, cross-impact analysis.

JEL Classification: O14, O18, R58.

\section{Introduction}

Smart specialisation strategy has moved in the recent years from a purely academic and theoretical concept towards a framework of regional development and innovation policy of the European Union. EU regions have been de facto coerced to identify their smart specialisation areas under a threat of blocking the possibility of applying for funds from the European Regional Development Fund assigned for strengthening research, technological progress, innovation and the improvement of access to high quality ICT services. It remains a point of debate in scientific literature and policy spheres if smart specialisation strategy is a promising approach to tackling development inequalities that characterise regions in Poland and in many other European countries (Hilkevics \& Hilkevica, 2017).

Polish regions have chosen very diverse approaches in identifying the areas of their smart specialisation. The results of those heterogeneous processes were lists of priorities some quite specific, some rather vague and general. For example, ICT, health and wellness and bio-economy are the smart specialisation areas of Lubelskie voivodship, whereas Opolskie voivodship has developed a long list of specific branches (wood industry, packaging, steel constructions to name a few). One may find little consistency and harmonisation between the priori- ties of different Polish regions. There is no coordination between the regional and national smart specialisation areas either (Piatkowski, Szuba, \& Wolszczak, 2014). For instance, ICT and life sciences are selected as a smart specialisation of many regions in Europe and beyond (Akhter, 2017; Niño-Amézquita, Legotin, \& Barbakov, 2017), which is contrary to the very idea of specialisation.

At the same time, some regions have fallen into temptation of reducing the process of identifying smart specialisation areas to an outsourced expert service provided by external consultants with little participation of local stakeholders (Nazarko, 2014).

In this paper the argument for a wider use of foresight methods in the formulation of smart specialisation strategy is offered. Results of a project entitled "Technological foresight NT FOR Podlaskie 2020. Regional strategy of nanotechnology development" are presented in the light of their value in the smart specialisation processes. Finally, a proposal of a methodology of a follow-up study is made.

\section{Role of foresight in the formulation of smart specialisation strategy}

There is no single universal methodology of identification and selection of smart specialisation areas 
as there is no single method to determine the competitive advantage of a region. Foray, David, and Hall (2011) point at the process of Schumpeterian entrepreneurial discovery as a fundamental source of smart specialisation, however they do not propose a consistent practical framework that could be implemented by the regions in a direct way. Piatkowski et al. (2014) divide potential methods of selecting smart specialisations into seven groups. One of the group bears the name of Foresight and is described as "an expert-driven process to explore a region's strengths and sectors with large potential for future development that defines strategic vision and directions for change" and one which "involves a comprehensive analysis and predictions about the development of future trends and markets" in the time-span of 5-20 years.

Foresight may be defined as a systematic process of exploring and shaping the future of technology, science, economy, environment or society. Its goal is to define emerging trends and phenomena in order to support decision makers in pursuing innovation policy that may yield maximum economic and social benefits in the long term future (Schatzmann, Schäfer, \& Eichelbaum, 2013). It has been applied in Poland for more than a decade (first pilot study started in 2004) and gained relative popularity long after it had been established in many other countries as an important policy informing instrument. To date there have been ca 50 foresight projects of national, regional and sectoral nature. Their findings and mobilised stakeholder base could be (or perhaps could have been) an important base for the smart specialisation processes. Unfortunately, to author's knowledge, a considerable stock of this non-trivial, expert-derived knowledge generated in the Polish foresight projects has not been widely used or disseminated.

Table 1. Roles of foresight in the process of developing and implementing smart specialisation strategy (source: own elaboration on the basis of Miles, Cassingena Harper, Georghiou, Keenan, \& Popper, 2008; Dinges, Biegelbauer, \& Wilhelmer, 2018)

\begin{tabular}{|c|c|}
\hline Foresight role & Description \\
\hline $\begin{array}{l}\text { Setting direction and pri- } \\
\text { oritising investment in } \\
\text { science, technology and } \\
\text { innovation }\end{array}$ & $\begin{array}{l}\text { Providing knowledge that helps set priorities and take decisions regarding the financ- } \\
\text { ing of particular initiatives } \\
\text { Stimulating research and innovation in the areas of foresight reflection } \\
\text { Reorienting the science and innovation system so that is meets the country's needs } \\
\text { (especially in the context of transition economies) } \\
\text { Help in benchmarking of the national science and innovation system in order to iden- } \\
\text { tify its strengths and weaknesses as well as existing threats and opportunities } \\
\text { Raising the status of science and innovation in the government as a means to attract } \\
\text { investment in those fields }\end{array}$ \\
\hline $\begin{array}{l}\text { Building a network } \\
\text { of stakeholders around } \\
\text { a common understand- } \\
\text { ing and vision }\end{array}$ & $\begin{array}{l}\text { Networking and strengthening relations by solving common problems (especially } \\
\text { when the pervious interaction was uncoordinated and lacked a „common language”) } \\
\text { Trust building between partners that are not used to collaboration with each other } \\
\text { Assistance in collaboration across administrative and epistemological boundaries } \\
\text { Revealing interdisciplinary dimensions in the areas of cooperation }\end{array}$ \\
\hline $\begin{array}{l}\text { Broadening the vision } \\
\text { and increasing } \\
\text { the knowledge related } \\
\text { to the future }\end{array}$ & $\begin{array}{l}\text { Increasing understanding and transformation of thinking about future challenges and } \\
\text { possibilities } \\
\text { Enabling the innovation system actors to review possible futures with regard to main } \\
\text { directions, drivers and rapid changes } \\
\text { Creating visions of the future which help the innovation system actors explore desir- } \\
\text { able and undesirable development paths and realise the choices that have impact on } \\
\text { those paths }\end{array}$ \\
\hline $\begin{array}{l}\text { Introducing new actors } \\
\text { to the strategic delibera- } \\
\text { tions }\end{array}$ & $\begin{array}{l}\text { Increasing the number of innovation system actors and the level of their engagement } \\
\text { in decision making processes; broadening the knowledge pool and better legitimisa- } \\
\text { tion of the democratic process of policy shaping } \\
\text { Expanding the scope and types of innovation system actors participating in the politi- } \\
\text { cal decision-making processes related to science, technology and innovation }\end{array}$ \\
\hline $\begin{array}{l}\text { Strengthening the mech- } \\
\text { anism of policy formula- } \\
\text { tion and coordination }\end{array}$ & $\begin{array}{l}\text { Delivering knowledge to political processes and public debate in the spheres where } \\
\text { science, technology and innovation play an important role } \\
\text { Improvement of policy implementation as the effect of the actions of people who en- } \\
\text { gage in introducing change into the policy governance subsystem thanks to the } \\
\text { knowledge and understanding gained during the foresight process }\end{array}$ \\
\hline
\end{tabular}


There are many ways foresight may strengthen the processes of search for smart specialisation and facilitate the implementation of smart specialisation strategies in the regions. A synthetic overview of the various aspects in which foresight reinforces smart specialisation strategy is presented in table 1 .

As noticed by Ejdys and Lulewicz-Sas (2013), foresight connects past, present and future, which enables the discovery of new opportunities rooted in the current regional context. One of few examples of how foresight may effectively facilitate the entrepreneurial discovery process is a project entitled "Mazovia Business Information Centre" in which enterprises themselves (which is unique in the Polish context) have developed scenarios of innovation-led development of Mazowieckie voivodship (Ejdys, 2013). The uniqueness of the project consisted in enterprises, not state administration or research entity, acting as leaders and primary stakeholders, which is in line with the current understanding of key drivers of regional sustainable development (Benešová, Kubičková, Michálková, \& Krošláková, 2018).

Another example of foresight providing information base for designing and implementing smart innovation policy is a project entitled "Technological foresight NT FOR Podlaskie 2020. Regional strategy of nanotechnology development" (Nazarko, 2011; Nazarko, Wnorowski, \& Kononiuk, 2011).

\section{3. "NT FOR Podlaskie 2020" - search for unconventional development paths}

The project represented an effort to study breakthrough technologies as potential sources of regional growth in a situation where the development of the traditional economic sectors fail to do so. It attempted to provide robust knowledge base to policy-makers and other stakelders in the process of region's development. It was based on a premise that the region needs more than just investment in physical infrastructure (Nazarko et al., 2015). The project employed the feed forward logic which assumes that it was possible to effectively anticipate alternative scenarios of future changes in the economic environment (Kononiuk \& Nazarko, 2014). Such anticipation should allow to chart a development trajectory for a region that does not imitate others but heads in the direction where the leaders will be in the future. The goals of the programme were the following (Kononiuk et al., 2012):
- to elaborate a strategy of nanotechnology development for the Podlaskie voivodship up to 2020,

- to identify and map critical nanotechnologies up to 2020 (Kononiuk \& Guda-nowska, 2013),

- to identify the most important factors influencing the development of nanotechnologies,

- to put forward scenarios of nanotechnology development,

- to stimulate a process of regional visionbuilding involving the key stakeholders.

In order to achieve the aforementioned goals an original methodology based on the intuitive logics school of scenario construction was developed (Figure 1). Methods and techniques were selected taking into account the aim and duration of the project, the planned funding as well as the availability of data, both quantitative and qualitative. Combination of the methods and techniques also took into account the diversification of the sources of knowledge: evidence, expertise, interaction, creativity (Popper, 2008).

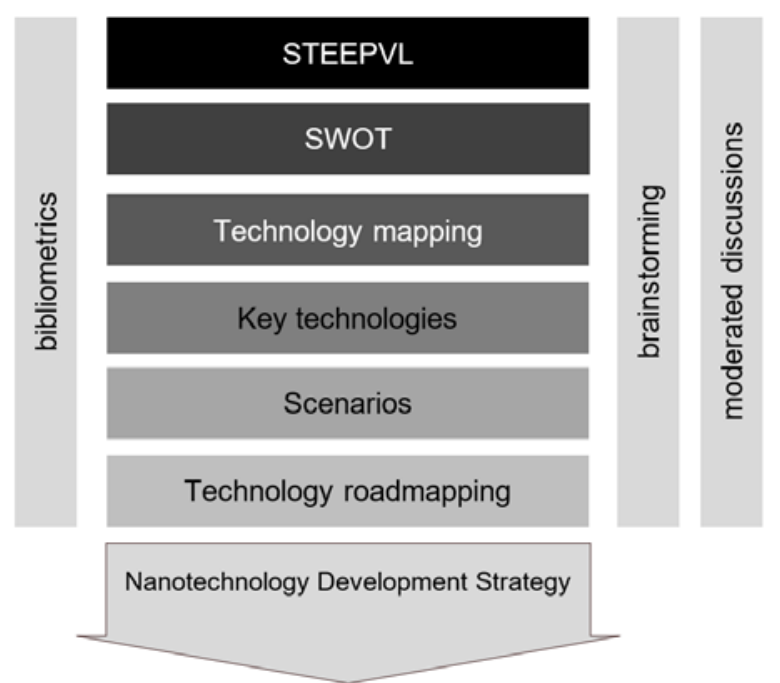

Figure 1. Methodology of the "Technological foresight NT FOR Podlaskie 2020. Regional strategy of nanotechnology development" project (source: Nazarko \& Kędzior, 2010)

The original study was conducted in 2011. It began with the identification of 21 STEEPVL (Social, Technological, Economic, Ecological, Political, Values, Legal) factors that were considered most important for the development of nanotechnology in Podlaskie region (Nazarko \& Kędzior, 2010). Next, a cross-impact analysis was carried out to better understand the inter-relations between the factors and to single out two most 
critical ones. As a result, the key research team and the engaged experts selected two key factors that constituted the axes of four scenarios of nanotechnology development in Podlaskie voivodship. The two factors were: 1) R\&D potential for nanotechnology in the region and 2) Effectiveness of regional networks of cooperation among business, science and administration. Consequently, four scenarios (enriched with the narratives determined by other STEEPVL factors) were developed (Figure 2).

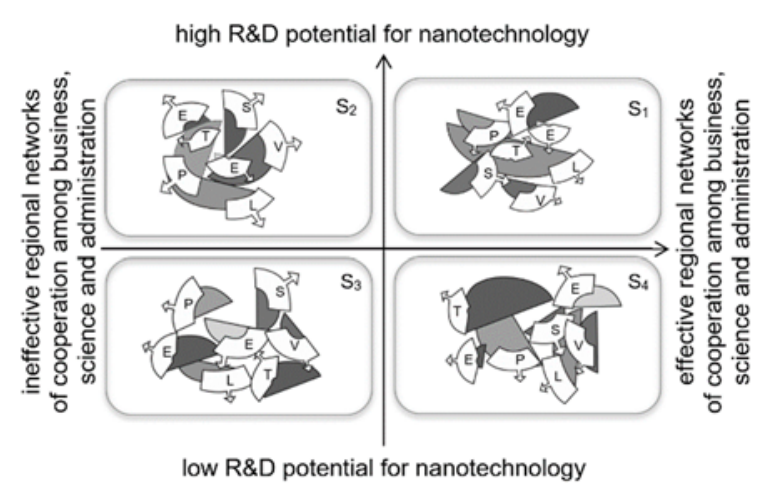

Figure 2. Alternative scenarios of nanotechnology development in Podlaskie province (source: Nazarko, 2013)

Basic characteristics of the four scenarios of nanotechnology development in Podlaskie province are presented in Table 2. Detailed narrratives of the scenarios are presented in Nazarko (2013).

Table 2. Framework of the four scenarios of nanotechnology development in Podlaskie province (source: Kononiuk et al., 2012)

\begin{tabular}{|l|l|l|}
\hline & \multicolumn{1}{|c|}{ Key drivers } & Scenario name \\
\hline $\mathbf{S}_{\mathbf{1}}$ & $\begin{array}{l}\text { High R\&D } \\
\text { Effective regional collabora- } \\
\text { tion of business, science and } \\
\text { administratio }\end{array}$ & $\begin{array}{l}\text { NANO: } \\
\text { New Dimension } \\
\text { of Podlaskie }\end{array}$ \\
\hline $\mathbf{S}_{\mathbf{2}}$ & $\begin{array}{l}\text { High R\&D } \\
\text { Ineffective regional collabora- } \\
\text { tion of business, science and } \\
\text { administratio }\end{array}$ & $\begin{array}{l}\text { NANO- } \\
\text { scattered } \\
\text { Podlaskie }\end{array}$ \\
\hline $\mathbf{S}_{3}$ & $\begin{array}{l}\text { Low R\&D } \\
\text { Ineffective regional collabora- } \\
\text { tion of business, science and } \\
\text { administratio }\end{array}$ & $\begin{array}{l}\text { NANO Indiffer- } \\
\text { ence in Pod- } \\
\text { laskie }\end{array}$ \\
\hline $\mathbf{S}_{4}$ & $\begin{array}{l}\text { Low R\&D } \\
\text { Effective regional collabora- } \\
\text { tion of business, science and } \\
\text { administratio }\end{array}$ & $\begin{array}{l}\text { NANO- } \\
\text { enthusiastic } \\
\text { Podlaskie }\end{array}$ \\
\hline
\end{tabular}

Basing on the elaborated scenarios and the identified key technologies with the highest importance and potential for Podlaskie voivodship a strategy of nanotechnology development was formulated. It is author's conviction that such strategies and accompanying analyses are a good entry point to the identification of sectors that are not just competitive today (a conventional basis for smart specialisation) but might be competitive in the future (a future-oriented smart specialisation approach).

\section{Smart specialisation strategy of Podlaskie voivodship}

To author's regret, smart specialisation areas announced by the regional administration of Podlaskie voivodship did not sufficiently take into account the body of knowledge developed in the course of the "NT FOR Podlaskie 2020" project despite the initial declarations of involvement and interest in implementing the results. Foresight methodology has not been used in the process of selecting smart specialisation areas. Although the document specifying Podlaskie's smart specialisation makes room for the so called emerging specialisations, it fails to identify any. Foresight approach would be indispensable in filling in this gap.

Table 3. Smart specialisation areas of Podlaskie voivodship (source: own elaboration on the basis of Plan rozwoju..., 2016)

\begin{tabular}{|l|l|}
\hline Specialisation core & $\begin{array}{l}\text { Emerging } \\
\text { specialisa- } \\
\text { tions } \\
\text { Innovation in the areas in which the } \\
\text { region is currently performing } \\
\text { above average }\end{array}$ \\
\begin{tabular}{l|} 
the areas of \\
high growth \\
potential
\end{tabular} \\
\hline $\begin{array}{l}\text { Agri-food sector and sectors con- } \\
\text { nected to them in the value chain }\end{array}$ & \\
\hline $\begin{array}{l}\text { Metal processing and machinery } \\
\text { sector, boatbuilding and sectors con- } \\
\text { nected to them in the value chain }\end{array}$ & \\
\hline $\begin{array}{l}\text { Eco-innovations, environmental sci- } \\
\text { ences and sectors connected to them } \\
\text { in the value chain (including renew- } \\
\text { able energy sources, energy-effi- } \\
\text { cient construction, effective wood } \\
\text { processing) }\end{array}$ & \\
\hline $\begin{array}{l}\text { Medical sector, life sciences and } \\
\text { sectors connected to them } \\
\text { in the value chain }\end{array}$ & \\
\hline
\end{tabular}


The reasons for excluding foresight methodology from the smart specialistation identification process in Podlaskie region is difficult to be definitely explained. Probaly the low sense of ownership of the results of "NT FOR Podlaskie 2020" on the part of regional authorities combined with insufficient level of foresight competences among the regional stakeholders were the decisive factors.

Due to the limitations of this paper the selection of smart specialisations presented in table 3 will not be analysed as far as the substance is concerned, however it is important point at some process related issues that raise author's concern. The task of identification of smart specialisations in Podlaskie voivodship was to a large extent transferred to an external consultancy. Involvement of regional stakeholders (entrepreneurs, academia, civil society), although formally registered, had little leverage on the final shape of the document. More transparency and employment of deliberative and participatory working methods would have been in concord with the idea of smart specialisation.

\section{Proposal of a follow-up study of nanotech- nology development in Podlaskie voivodship}

Although, on the policy level, there is currently no need to update the smart specialisations elaborated by the Polish regions, the situation of Podlaskie voivodship is peculiar in the sense that the region does not formally have a Regional Innovation Strategy. Region's smart specialisations are listed in a document called "Plan of entrepreneurship development on the basis of smart specialisations of Podlaskie voivodship in the years 2015-2020+". In this context, the author proposes that a sound and comprehensive regional innovation strategy is created that will contain an updated list of smart specialisations, including the emerging ones. For the purpose of identifying the latter, a follow-up study of nanotechnology development in Podlaskie voivodship is proposed by the author. Framework of the methodology of such a study is presented in Figure 3.

The advantage of the proposed methodology is its scalability - one may involve in the study as many stakeholders as one wishes (or is able to mobilise) without the need to modify the methodology and without a significant increase in the cost of the study. Weakness of such study may be seen in the very nature of the employed methods (results heavily dependent on the selection of experts) and the probable inability to survey the very same experts as during the original research in 2011. Nevertheless, a careful and conscious interpretation of results enriched with knowledge from other sources could provide crucial early signals of trend shifts or new trend emergence.

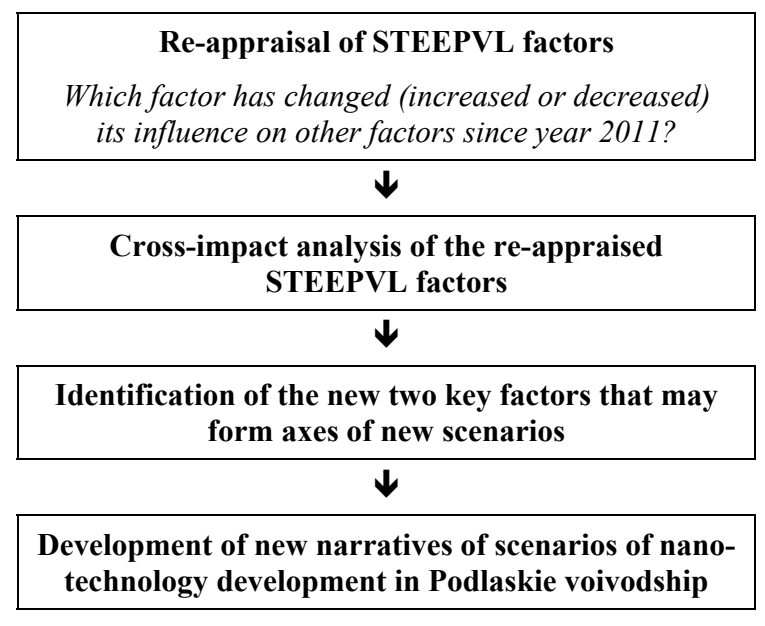

Figure 3. Framework of the methodology of the follow-up study of nanotechnology development in

Podlaskie voivodship (source: own elaboration)

\section{Conclusions}

More extensive use of tools from the field of foresight and future studies may lead to smarter specialisations - the ones that may generate extraordinary growth not necessarily now but in the future. It is author's conviction that this is exactly the role of public intervention in the area of science, technology and innovation - to support not just the current winners but also to invest in the potential future winners. "Technology foresight NT FOR Podlaskie 2020" project led to the identification of the most important factors of the nanotechnology development in the region as well as the key technologies that might contribute to creating a competitive advantage of the province.

Naturally, betting on a particular technological niche as a potential motor of regional development is a risky endeavour. Therefore, regional authorities typically choose a "business as usual" approach which, on one hand, guarantees no spectacular progress but, on the other, no spectacular failure. Nevertheless, there seem to be no risk-free approaches to creating new opportunities for an accelerated growth in the regions that have been lagging behind the European average. Identification of key technologies as well as modern (Siderska \& Jadaan, 2018) and sustainable (R. Popper, M. Popper, \& Velasco, 2017) manufacturing methods, formulating roadmaps for obtaining these technologies - all that should be, in author's 
opinion, accompanied by an in-depth study of the social and intellectual capital of an area (Gudanowska, Alonso, \& Törmänen, 2018). Creating conducive environment for a synergy between technological and human aspects of development might result in an increased pace of economic and social development of a region.

\section{Funding}

The research for this paper has been conducted in the framework of the project no. S/WZ/4/2015 financed from the funds of the Ministry of Science and Higher Education of Poland.

\section{Disclosure statement}

Author declares that the work was not a subject of any competing financial, professional, or personal interests from other parties.

\section{References}

Akhter, F. (2017). Unlocking digital entrepreneurship through technical business process. Entrepreneurship and Sustainability Issues, 5(1), 36-42. https://doi.org/10.9770/jesi.2017.5.1(3)

Benešová, D., Kubičková, V., Michálková, A., \& Krošláková, M. (2018). Innovation activities of gazelles in business services as a factor of sustainable growth in the Slovak Republic. Entrepreneurship and Sustainability Issues, 5(3), 452-466. https://doi.org/10.9770/jesi.2018.5.3(3)

Dinges, M., Biegelbauer, P., \& Wilhelmer, D. (2018). The tower of Babylon in the governance of research. Technology and Innovation: Participatory Foresight as a Method of Policy Coordination, Futures (in press). https://doi.org/10.1016/j.futures.2018.03.018

Ejdys, J. (2013). Regionalny foresight gospodarczy. Scenariusze rozwoju lokalnego województwa mazowieckiego. Warszawa: Związek Pracodawców Warszawy i Mazowsza.

Ejdys, J., \& Lulewicz-Sas A. (2013). Inteligentna specjalizacja - nowy kierunek polityki regionalnej Unii Europejskiej. Samorzad Terytorialny, 5, 23-33.

Foray, D., David, P. A., \& Hall, B. H. (2011). Smart specialization. From academic idea to political instrument, the surprising career of a concept and the difficulties involved in its implementation. MTEI Working Paper 2011-01, École Polytechnique Fédérale de Lausanne, Lausanne.

Gudanowska, A. E., Alonso, J. P., \& Törmänen, A. (2018). What competencies are needed in the production industry? The case of the Podlaskie Region. Engineering Management in Production and Services, 10(1), 65-74. https://doi.org/10.1515/emj-2018-0006

Hilkevics, S., \& Hilkevica, G. (2017). New information technologies use for Latvian stock companies financial health evaluation. Entrepreneurship and Sustainability Issues, 5(2), 178-189.

https://doi.org/10.9770/jesi.2017.5.2(1)
Kononiuk, A., \& Nazarko, J. (2014). Scenariusze $w$ antycypowaniu $i$ ksztaltowaniu przyszłości. Warszawa: Wolters Kluwer.

Kononiuk, A., Nazarko, Ł., Nazarko, J., Ejdys, J., Halicka, K., Glińska, U., \& Gudanowska, A. (2012). Nanotechnology for Podlaskie 2020. European Foresight Platform Brief No 235.

Kononiuk, A., Gudanowska, A. (Eds.). (2013). Kierunki rozwoju nanotechnologii $w$ województwie podlaskim. Mapy. Marszruty. Trendy. Białystok: Oficyna Wydawnicza Politechniki Białostockiej.

Miles, I., Cassingena Harper, J., Georghiou, L., Keenan, M., \& Popper, R. (2008). The many faces of foresight. In: L. Georghiou, J. Cassingena Harper, M. Keenan, I. Miles, R. Popper (Eds.), The handbook of technology foresight. Concepts and practice. Northampton: Edward Elgar Publishing Inc.

Nazarko, J., \& Kędzior, Z. (Eds.). (2010). Uwarunkowania rozwoju nanotechnologii w województwie podlaskim: wyniki analiz STEEPVL i SWOT. Białystok: Oficyna Wydawnicza Politechniki Białostockiej.

Nazarko, J. (2011). Kształtowanie polityki proinnowacyjnej regionu np. foresightu technologicznego «NT FOR Podlaskie 2020», Optimum. Studia Ekonomiczne, 2(50), 241-251.

Nazarko, J., Wnorowski, H., \& Kononiuk, A. (Eds.). (2011). Analiza strukturalna czynników rozwoju nanotechnologii $w$ województwie podlaskim. Białystok: Oficyna Wydawnicza Politechniki Białostockiej.

Nazarko, J. (Ed.). (2013). Podlaska strategia rozwoju nanotechnologii do 2020 roku. Przełomowa wizja regionu. Białystok: Oficyna Wydawnicza Politechniki Białostockiej.

Nazarko, J., Radziszewski, P., Dębkowska, K., Ejdys, J., Gudanowska, A., Halicka, K., Kilon, J., Kononiuk, A., Kowalski, K., Król, J., Nazarko, Ł., Sarnowski, M. \& Vilutiene,T. (2015). Foresight study of road pavement technologies. Procedia Engineering, 122, 129-136. http://doi.org/10.1016/j.proeng.2015.10.016

Nazarko, Ł. (2014). Inteligentne specjalizacje polskich regionów - przyczynek do ewaluacji. Przedsiębiorczość $i$ Zarzadzanie, 8(1), 247-262.

Niño-Amézquita, J., Legotin, F., \& Barbakov, O. (2017). Economic success and sustainability in pharmaceutical sector: a case of Indian SMEs. Entrepreneurship and Sustainability Issues, 5(1), 157-168. https://doi.org/10.9770/jesi.2017.5.1(13)

Piatkowski, M., Szuba, T., \& Wolszczak, G. (2014). Review of national and regional research and innovation strategies for smart specialization (RIS3) in Poland. World Bank Group: Washington, DC.

Plan rozwoju przedsiębiorczości $w$ oparciu o inteligentne specjalizacje województwa podlaskiego na lata 2015$2020+$ (RIS3). Annex to the Resolution No 120/1431/ 2016 of the Administration of Podlaskie Voivodship from 1 March 2016.

Popper, R. (2008). Foresight methodology. In L. Georghiou, J. Cassingena Harper, M. Keenan, I. Miles, \& R. Popper (Eds.), The handbook of technology foresight. Concepts and practice. Northampton: Edward Elgar Publishing Inc.

Popper, R., Popper, M., \& Velasco, G. (2017). Towards a more responsible sustainable innovation assessment and management culture in Europe. Engineering Management in Production and Services, 9(4), 7-20. https://doi.org/10.1515/emj-2017-0027 
Schatzmann, J., Schäfer, R., \& Eichelbaum, F. (2013). Foresight 2.0 - definition, overview \& evaluation. European Journal of Futures Research, (December 2013), $1-15$.

https://doi.org/10.1007/s40309-013-0015-4
Siderska, J., \& Jadaan, K. S. (2018). Cloud manufacturing: a service-oriented manufacturing paradigm. Engineering Management in Production and Services, 10(1), 22-31.

https://doi.org/10.1515/emj-2018-0002 